\title{
RESPONSE OF DROUGHT-TOLERANT CORN TO VARYING IRRIGATION LEVELS IN THE TEXAS HigH PLAINS
}

\author{
S. A. O’Shaughnessy, M. Kim, M. A. Andrade, P. D. Colaizzi, S. R. Evett
}

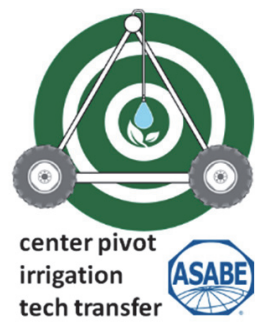

Collection

\begin{abstract}
Corn (Zea mays L.) for grain continues to be an important crop for livestock feed in the Texas High Plains (THP) region despite lackluster prices. It offers greater crop water productivity compared with other crops grown in the region but also has a relatively high water requirement, which must be met by irrigation. The sole water resource in the region is the Ogallala Aquifer, which is declining because withdrawals exceed recharge, and this is of major concern. Producers are interested in the performance of drought-tolerant (DT) corn, but data on DT crop production functions are limited. From 2015 to 2017, studies of DT corn response to different irrigation treatments were conducted in the THP at Bushland, Texas. Results showed that grain yields, seasonal evapotranspiration (ET $)$, and crop water use efficiency (WUE) varied significantly between seasons and among different DT hybrids. Comparisons between a mid-season (MS) and an early-maturing (EM) hybrid showed: (1) at the severe deficit irrigation treatment level, grain yields were low, but the EM hybrid produced $400 \%$ more grain; (2) at the moderate deficit irrigation treatment level, grain yields and ET $T_{c}$ were similar; and (3) at the full irrigation treatment level, the EM hybrid required $75 \mathrm{~mm}$ less water, but it produced $24 \%$ less grain. Nonhail damaged MS DT corn produced grain yields that were numerically greater than conventional corn grown in the THP in an optimal year. However, during drought seasons, DT hybrid response was not improved over conventional hybrids under severe deficit irrigation. This study demonstrated that MS DT corn hybrid P1151AM, irrigated at a level that fully met evapotranspiration demand, resulted in grain yield and WUE levels that were near the upper limits for corn produced in the THP. Further research is needed to determine the constancy of response among different DT hybrids under favorable and drought conditions.
\end{abstract}

Keywords. Center pivot, Deficit irrigation, Early-maturing corn, Hail damage, Mid-season corn, Variable-rate irrigation, Water use efficiency.

I $\mathrm{n}$ the Texas High Plains (THP) region, grain production for livestock is a major driver for irrigated agriculture, and corn remains the main crop for cattle feed. However, corn requires more water than other major crops grown in the area to maximize grain yields and water use efficiency. Corn yields in the region are highly variable from

\footnotetext{
cc) $\$$ The authors have paid for open access for this article. This (c) ${ }_{\text {BY NG ND }}$ work is licensed under a Creative Commons AttributionNonCommercial-NoDerivatives 4.0 International License https://creative commons.org/licenses/by-nc-nd/4.0/

Submitted for review in November 2018 as manuscript number NRES 13234; approved for publication approved for publication as part of the Center-Pivot Irrigation Tech Transfer Collection by the Natural Resources \& Environmental Systems Community of ASABE in March 2019.

Mention of company or trade names is for description only and does not imply endorsement by the USDA. The USDA is an equal opportunity provider and employer.

The authors are Susan A. O'Shaughnessy, Research Agricultural Engineer, USDA-ARS Soil and Water Management Research Unit, Bushland, Texas; MinYoung Kim, Agricultural Engineer, National Institute of Agricultural Sciences, Rural Development Administration, Jeonju, South Korea; Manuel A. Andrade, ORISE Postdoctoral Fellow, Paul D. Colaizzi, Research Agricultural Engineer, and Steven R. Evett, Research Soil Scientist, USDA-ARS Soil and Water Management Research Unit, Bushland, Texas. Corresponding author: Susan O'Shaughnessy, 2300 Experiment Station Road, Bushland, TX 79012; phone: 806-3565770; e-mail: susan.oshaughnessy@ars.usda.gov.
}

season to season depending on several factors, including soil type, the amount of water stored in the soil, the timing and amount of seasonal precipitation and irrigation, evaporative demand, severe weather, and cultivar response (Lyle and Bordovsky, 1995; Howell et al., 1998; Tolk et al., 1998; Klocke et al., 2011). Irrigation helps to stabilize corn yields (Klocke et al., 2007); however, large withdrawals from the Ogallala Aquifer are of major concern, and producers are under pressure to irrigate more efficiently and use less water for agriculture (Wagner, 2012; Weinheimer et al., 2012). Undoubtedly, irrigation application efficiency has improved since the conversion from furrow to sprinkler irrigation, and now more than $77 \%$ of irrigated acres in Texas are served by center-pivot sprinklers (USDA-NASS, 2014), while in the THP region that percentage is greater than $85 \%$. Producers in the region are known for using low-pressure center-pivot systems designed for efficiency (Amosson et al., 2014) and application methods intended to minimize evaporative losses to surface evaporation, wind, and high temperatures, such as low-elevation spray application (LESA) and low-energy precision application (LEPA) (Colaizzi et al., 2004).

Drought-tolerant (DT) corn hybrids became available in 2011 with the release of Pioneer Optimum AQUAmax and Syngenta Artesian, traditionally bred product lines based on experiments that demonstrated long-term improvement of 
grain yield under drought conditions (Mannion and Morse 2012; Cooper et al., 2014; Gaffney et al., 2015). A third DT corn hybrid, and the only DT corn biotechnology product on the market, was Genuity DroughtGard from Monsanto (Nuccio et al., 2018). Gaffney et al. (2015) reported that AQUAmax hybrids yield greater (6.5\%) than industry-leading hybrids under water-limited conditions during flowering or grain-fill, and AQUAmax hybrids yielded $1.9 \%$ greater under favorable conditions. Data were accumulated from research trials conducted in different locations within the U.S. Corn Belt from 2008 to 2010 and from on-farm testing from 2010 to 2012. Adee et al. (2016) reported yield advantages of 5\% to 7\% for DT hybrids (AQUAmax and DroughtGard) grown alongside non-DT hybrids in medium to high ET environments within the Central High Plains.

If DT corn hybrids produce yields similar to conventional (CONV) hybrids in the THP, then coupling efficient irrigation design with DT corn and prudent irrigation scheduling could aid producers in reducing irrigation amounts while maintaining profitable yields. Yield responses for DT corn hybrids grown in the THP have shown mixed results relative to CONV corn hybrids. Mounce et al. (2016) reported no significant difference in grain yields at Bushland, Texas, between Pioneer varieties P0876HR (DT hybrid) and 33Y75 (CONV hybrid) grown in 2013 (a relatively dry year) and 2014 (an optimal year with plentiful in-season precipitation and low maximum air temperatures). However, direct soil water measurements for each hybrid demonstrated that the mean cumulative irrigation amounts required by the DT hybrid in the 2013 and 2014 growing seasons were less (25 to $50 \mathrm{~mm}$ ) compared with the CONV hybrid at each irrigation treatment level. Hao et al. (2015a) reported that two (P1151HR and P1564HR) of four AQUAmax hybrids (P1151HR, P1324HR, P1498HR, and P1564HR) grown during three drought years (2011-2013) in Etter, Texas (located in the northern part of the THP region) consistently produced significantly greater grain yields and WUE in treatment plots irrigated at $50 \%$ of full $\mathrm{ET}_{c}$. Yield advantages ranged from $8 \%$ to $21 \%$ as compared with CONV Pioneer hybrid 33D49. In 2012 and 2013, these same DT hybrids produced significantly greater yields and WUE at irrigation treatments of $75 \%$ of $\mathrm{ET}_{c}$. At full irrigation, grain yields were similar among DT and CONV hybrids. In a subsequent study, Hao et al. (2016) reported that yields from DT corn hybrid P1151HR grown in the relatively wetter year of 2014 outperformed grain yields produced by CONV hybrid 33D49 by $19 \%$ and $40 \%$ at irrigation treatment levels of $100 \%$ and $50 \%$ of $\mathrm{ET}_{c}$, respectively. In studies conducted in 2014 and 2015 in Etter, Zhao et al. (2018) reported that DT hybrids
P1151AM and $\mathrm{N} 75 \mathrm{H}$ produced grain yields similar to those of CONV hybrids 33D53AM and N74R irrigated at $100 \%$ of $\mathrm{ET}_{c}$ in 2014 and 2015. In 2014, the grain yield and WUE were significantly greater for P1151AM than for both CONV hybrids. Greater grain yield was attributed to greater biomass, harvest index, kernel weight, and kernel number.

While the performance of DT corn hybrids relative to CONV hybrids is mixed, these studies help allay concern that DT hybrids will underperform in moderate- to highyield environments, a topic investigated by Chang et al. (2013) and Lindsey and Thomison (2016). However, more information is needed to determine if early-maturing DT hybrids provide substantial savings in irrigation without significant yield penalties compared with mid-season DT corn hybrids, and whether there is consistency in DT corn grain yield and WUE performance at mild-deficit irrigated levels for corn produced in the THP region. In this study, we used direct soil water measurements from each type of hybrid treatment plot to determine how much water to apply to each different hybrid during a seven-day period, as described by Mounce et al. (2016). This method of irrigation scheduling is unique compared to other studies of DT corn in the THP region. The objectives of this article are to: (1) summarize the crop response, yield, $\mathrm{ET}_{c}$, and WUE of mid- and earlyseason DT corn hybrids grown in Bushland, Texas, over the past three years; and (2) compare these recent data to historical information for corn grown in the region.

\section{Materials ANd Methods}

The experiments were conducted at the USDA-ARS Conservation and Production Research Laboratory (CPRL) in Bushland, Texas $\left(35^{\circ} 11^{\prime} \mathrm{N}, 102^{\circ} 6^{\prime} \mathrm{W}\right.$, elevation $1190 \mathrm{~m}$ above mean sea level). The soils are Pullman clay loam (fine, superactive, mixed, thermic torretic Paleustoll; USDANRCS, 2010). All corn hybrids were of Pioneer Optimum AQUAmax variety with comparative relative maturity (CRM) ranging from 96 to 115 days. The planting dates, seeding rates, and irrigation treatment levels are presented in table 1 . The field capacity $\left(0.33 \mathrm{~m}^{3} \mathrm{~m}^{-3}\right)$ and wilting point $\left(0.19 \mathrm{~m}^{3} \mathrm{~m}^{-3}\right)$ water contents were assumed uniform across the center-pivot field. The climate is semi-arid with an average annual precipitation of $470 \mathrm{~mm}$.

Corn was planted under variable-rate irrigation (VRI) center-pivot systems (six-span and three-span) outfitted with zone control, as described by O'Shaughnessy et al. (2013). The VRI system allowed randomized irrigation treatments in radial and arc-wise directions. For each season, only onehalf of the field was planted, allowing rotation of the crop to

Table 1. Summary of corn hybrids planted, planting dates, planting rates, and irrigation treatment levels for the 2015 -2017 growing seasons in Bushland, Texas.

\begin{tabular}{|c|c|c|c|c|c|c|}
\hline Year & $\begin{array}{c}\text { Hybrid } \\
\text { (DuPont Pioneer) }\end{array}$ & $\begin{array}{c}\text { Drought } \\
\text { Tolerance } \\
\text { Rating }^{[\mathrm{a}]} \\
\end{array}$ & $\begin{array}{c}\text { Comparative } \\
\text { Relative Maturity } \\
\text { (days) }\end{array}$ & Planting Date & $\begin{array}{l}\text { Seeding Rate } \\
\left(\text { seeds } \mathrm{ha}^{-1}\right)\end{array}$ & Irrigation Levels ${ }^{[\mathrm{b}]}$ \\
\hline \multirow[t]{2}{*}{2015} & P0157AM (DT) & 9 & 101 & June 23 (DOY 174) & 79,000 & $100 \%, 75 \%, 50 \%$ \\
\hline & P9697AM (DT) & 9 & 96 & June 23 (DOY 174) & 79,000 & $100 \%, 75 \%, 50 \%$ \\
\hline \multirow[t]{2}{*}{2016} & P1151AM (DT) & 9 & 111 & May 13 (DOY 134) & 79,000 & $100 \%, 80 \%, 50 \%, 30 \%, 0 \%$ \\
\hline & P0157AM (DT) & 9 & 101 & June 16 (DOY 168) & 79,000 & $100 \%, 80 \%, 50 \%, 30 \%$ \\
\hline 2017 & P1151AM (DT) & 9 & 111 & May 17 (DOY 137) & 84,000 & $100 \%, 80 \%, 50 \%, 30 \%, 0 \%$ \\
\hline
\end{tabular}

[a] Dupont Pioneer Corn Seed Guide (2015-2017) (https:/www.pioneer.com/home/site/us/products/corn/seed-guide).

[b] Replenishment of soil water depletion to field capacity 
the fallowed half the following season. Seed was planted in concentric rows spaced $0.76 \mathrm{~m}$ apart, with plots at least 12 rows wide and arranged in a split-plot design with hybrid and irrigation treatment levels as main effects. Cultural practices were comparable to those of producers in the region practicing conventional tillage. Nitrogen and phosphorous were applied prior to bed preparation to obtain target yields of $1.42 \mathrm{~kg} \mathrm{~m}^{-2}$ (225 bushels per acre) after composite soil sample analyses were performed in the early spring of each year by a commercial company.

Irrigation treatments were based on replenishment of a percentage of soil water depletion to field capacity in the top $1.5 \mathrm{~m}$ of soil and based on weekly neutron probe (NP) readings. In 2015, the three treatment levels were full, mild deficit, and moderate deficit, designated $I_{100}, I_{75}$, and $I_{50}$, respectively. In 2016 and 2017, there were five irrigation treatment levels, including a mild deficit irrigation treatment level that was slightly different at $I_{80}$, a severe deficit treatment $\left(I_{30}\right)$, and a rainfed treatment $\left(I_{0}\right)$. The treatment designations were labeled $I_{x}$, where $x$ indicates the percent replenishment of soil water depletion to field capacity. The NP meters (model 503DR1.5, Instrotek, Campbell Pacific Nuclear, Martinez, Cal.) were field-calibrated using methods described by Evett (2008). The NP access tubes were placed in the center of each plot to a depth of $2.3 \mathrm{~m}$ so that changes in the soil water profile $(\Delta S)$ could be accurately determined within the root zone.

Weather data were collected from standalone weather stations located in each center-pivot field. Measurements included solar irradiance by a pyranometer (model LI-200R, LI-COR Biosciences, Inc., Lincoln, Neb.), air temperature and relative humidity by an encapsulated sensor (model HC2S3, Rotronic Instrument Corp., Hauppauge, N.Y.), precipitation by a tipping-bucket rain gauge (model TE525, Texas Electronics, Dallas, Tex.), and wind speed by a cup anemometer (Wind Sentry 03101, Campbell Scientific, Logan, Utah). Data were sampled every $5 \mathrm{~s}$ and averaged and stored every 1 min with a datalogger (model CR1000, Campbell Scientific). This information was used to calculate reference evapotranspiration ( $\mathrm{ET}_{o}$; ASCE, 2005). The soil water balance method was used to calculate crop water use $\left(\mathrm{ET}_{c}\right)$ for each cropping season using equation 1 :

$$
\mathrm{ET}_{c}=I+P+F-\Delta S-R
$$

where $I$ is the amount of irrigation water applied $(\mathrm{mm}), P$ is precipitation $(\mathrm{mm}), F$ is flux across the lower boundary of the control volume, and $R(\mathrm{~mm})$ is runoff. The value of $F$ was set to zero because NP data from the bottom two measurement depths indicated negligible soil water flux. All studies were arranged in a split-plot design in which whole plots were hybrids planted in a concentric pattern and subplots were irrigation treatments. Furrows were diked for rainfall retention and to mitigate runoff, so that $R=0$ (Lyle and Dixon, 1977).

In 2015, the field was planted on June 23 with two earlymaturing (EM) corn hybrids (P0157AM and P9697AM). The crop was irrigated using low-elevation spray application (LESA), with the drops spaced in every other furrow and the nozzles approximately $0.33 \mathrm{~m}$ above the ground. Similar to the previous study, there were five replications of each hybrid by irrigation treatment, and the irrigation treatment levels were $I_{100}, I_{75}$, and $I_{50}$.

To investigate the differences in crop response between a mid-season (MS) DT hybrid (P1151AM) and an EM DT hybrid (P0157AM), the two hybrids were planted in the same year (2016) but approximately 30 days apart. The MS DT hybrid was planted under the three-span VRI system in midMay, and the EM hybrid was planted under the six-span VRI system in mid-June (table 1). The irrigation treatment levels were $I_{100}, I_{80}, I_{50}, I_{30}$, and $I_{0}$ for the MS hybrid and $I_{100}, I_{50}$, and $I_{30}$ for the EM hybrid. Both fields were irrigated using LESA, and there were six replications for each type of treatment plot.

Finally, in 2017, MS DT hybrid P1151AM was planted a second year in mid-May under the three-span VRI system and irrigated using LESA at the same five treatment levels as in 2016. Crop response between the two seasons for this MS DT hybrid was compared between the two years.

Water use efficiency (WUE) was defined as:

$$
\mathrm{WUE}=\frac{\text { Economic yield }}{\mathrm{ET}_{c}}
$$

where economic yield is the wet-basis grain at $15.6 \%$ moisture, and $\mathrm{ET}_{c}$ spans from planting to harvest (Howell, 2001).

Growing degree days (GDD) were calculated as (McMaster and Wilhelm, 1997):

$$
\mathrm{GDD}=\frac{\left(T_{\max }+T_{\min }\right)}{2}-T_{\text {base }}
$$

where $T_{\min }$ (minimum daily air temperature) and $T_{\max }$ (maximum daily air temperature) were constrained at $10^{\circ} \mathrm{C}$ and $30^{\circ} \mathrm{C}$, respectively, and $T_{\text {base }}$ is the crop-specific baseline development temperature $\left(10^{\circ} \mathrm{C}\right.$ for corn; Gilmore and Rogers, 1958).

Mean crop responses, grain yield, $\mathrm{ET}_{c}$, and WUE were analyzed for differences using the mixed linear model procedure of PROC MIXED (Littell, 2006) (SAS ver. 9.4, SAS Institute, Inc., Cary, N.C.). Main effects were hybrid and irrigation treatment levels. Student's t-test was used to compare mean values.

\section{Results \\ Climatic Conditions}

Annual and within-season precipitation (June through October) was less than average in 2016 and greater than average in 2015 and 2017 (table 2). Hailstorms occurred on 13 June and 8 July 2015, 13 June 2016, and 2 July 2017. ETo was greatest in June and July for each of the three years. In 2015, precipitation in June, July, and October was above average. Drought conditions prevailed in May through early August of 2016 and in May and June of 2017.

\section{COMPARISON OF TWO EARLY-MATURING DT CORN HYBRIDS}

In $2015,50 \%(264 \mathrm{~mm})$ of total precipitation for the growing season occurred during the vegetative growth stage, 
Table 2. Mean meteorological data reported monthly for growing seasons 2015-2017 at Bushland, Texas.

\begin{tabular}{|c|c|c|c|c|c|c|c|c|c|}
\hline & & \multirow{2}{*}{$\begin{array}{l}\text { Cumulative } \\
\text { Precipitation } \\
(\mathrm{mm})\end{array}$} & \multicolumn{2}{|c|}{ Air Temperature } & \multicolumn{2}{|c|}{ Relative Humidity } & \multirow{2}{*}{$\begin{array}{c}\text { Solar } \\
\text { Irradiance } \\
\left(\mathrm{MJ} \mathrm{m}^{-2} \mathrm{~d}^{-1}\right)\end{array}$} & \multirow{2}{*}{$\begin{array}{l}\text { Wind } \\
\text { Speed } \\
\left(\mathrm{m} \mathrm{s}^{-1}\right) \\
\end{array}$} & \multirow{2}{*}{ 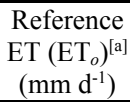 } \\
\hline \multicolumn{2}{|c|}{ Year and Month } & & $\begin{array}{c}\text { Maximum } \\
\left({ }^{\circ} \mathrm{C}\right)\end{array}$ & $\begin{array}{c}\text { Minimum } \\
\left({ }^{\circ} \mathrm{C}\right)\end{array}$ & $\begin{array}{l}\text { Maximum } \\
(\%)\end{array}$ & $\begin{array}{c}\text { Minimum } \\
(\%)\end{array}$ & & & \\
\hline \multirow[t]{5}{*}{2015} & June & 74 & 30.6 & 17.0 & 94.5 & 38.0 & 23.4 & 4.1 & 6.1 \\
\hline & July & 227 & 32.6 & 24.4 & 94.8 & 35.1 & 23.5 & 3.3 & 5.5 \\
\hline & Aug. & 65 & 31.7 & 24.0 & 90.3 & 36.5 & 22.6 & 2.9 & 4.9 \\
\hline & Sept. & 21 & 30.0 & 22.4 & 87.6 & 32.8 & 19.4 & 3.3 & 5.2 \\
\hline & Oct. & 128 & 22.4 & 15.9 & 95.0 & 46.0 & 12.8 & 3.0 & 2.5 \\
\hline \multirow[t]{6}{*}{2016} & May & 31.5 & 25.3 & 9.3 & 88.8 & 30.8 & 24.3 & 4.7 & 5.9 \\
\hline & June & 35 & 33.0 & 17.2 & 90.2 & 27.1 & 26.2 & 3.9 & 7.0 \\
\hline & July & 23 & 36.0 & 19.2 & 83.0 & 22.7 & 25.8 & 3.7 & 7.5 \\
\hline & Aug. & 178 & 31.0 & 17.0 & 97.4 & 36.3 & 20.7 & 3.0 & 4.7 \\
\hline & Sept. & 21 & 28.9 & 14.4 & 96.4 & 39.0 & 19.5 & 3.3 & 4.1 \\
\hline & Oct. & 0 & 27.2 & 8.9 & 81.9 & 22.9 & 15.9 & 4.7 & 5.6 \\
\hline \multirow[t]{6}{*}{2017} & May & 15.6 & 27.4 & 8.0 & 87.8 & 21.5 & 25.3 & 4.3 & 5.5 \\
\hline & June & 44.2 & 33.7 & 15.1 & 96.0 & 39.6 & 24.6 & 4.1 & 6.4 \\
\hline & July & 107.6 & 35.1 & 18.0 & 91.4 & 33.0 & 23.4 & 3.4 & 5.7 \\
\hline & Aug. & 189.4 & 29.8 & 16.3 & 98.5 & 49.9 & 20.6 & 3.0 & 3.8 \\
\hline & Sept. & 40.4 & 27.9 & 12.7 & 90.7 & 41.3 & 17.1 & 3.5 & 3.4 \\
\hline & Oct. & 84.0 & 23.0 & 6.4 & 94.9 & 42.2 & 15.0 & 4.4 & 3.4 \\
\hline
\end{tabular}

[a] Reference evapotranspiration (ET $)$ was calculated using standardized methods (ASCE 2005).

while $16 \%$ (89 $\mathrm{mm})$ occurred during the reproductive stages, and $27 \%$ occurred after physiological maturity. Harvest was delayed until early November because of difficulty entering the muddy fields.

Cumulative seasonal irrigation amounts were 254, 190, and $127 \mathrm{~mm}$ for the P0157AM hybrid and 290, 218, and $145 \mathrm{~mm}$ for the P9697AM hybrid in the $I_{100}, I_{75}$, and $I_{50}$ irrigation treatment levels, respectively. The P0157AM hybrid required 36 and $28 \mathrm{~mm}$ less at the $I_{100}$ and $I_{75}$ irrigation treatment levels, respectively, while producing similar mean yields. The first irrigation event was applied at the 10-leaf stage, and then two weeks later at tassel, and then every 3 to 5 days throughout the reproductive stages. Irrigation for both hybrids was terminated after September 23 (DOY 266) when P0157AM was in the early dent stage and P9697AM was in the late dent stage. Average plant-available water in the top $1.5 \mathrm{~m}$ profile at the time of termination in the $I_{100}$ treatment was 166 and $160 \mathrm{~mm}$ for P0157AM and P9697AM, respectively.
Overall mean biomass, kernels per ear, and kernel weight were similar between hybrids; however, harvest index (HI) (ratio of biomass to grain mass) was greater for the P0157AM hybrid. Grain yield response to $\mathrm{ET}_{c}$ was linear for both hybrids (fig. 1). Data analyses indicated that overall grain yield and WUE were similar between hybrids; however, overall mean $\mathrm{ET}_{c}$ was significantly greater for the P9697AM hybrid. At the $I_{100}$ and $I_{75}$ treatment levels, grain yields and WUE were similar between hybrids. However, at the $I_{50}$ treatment level, grain yield and WUE were significantly greater for the P9697AM hybrid (table 3). Seasonal $\mathrm{ET}_{c}$ was significantly greater for the P9697AM hybrid at the $I_{75}$ treatment level. Grain yield and WUE for the EM hybrids in the current study were less than the values reported by Mounce et al. (2016) for DT hybrid P0876HR (i.e., yield of 0.99 and $1.32 \mathrm{~kg} \mathrm{~m}^{-2}$ and WUE of 1.98 and $2.63 \mathrm{~kg} \mathrm{~m}^{-3}$ for 2013 and 2014, respectively) at the CPRL. WUE values were much smaller in this study due to the large amounts of

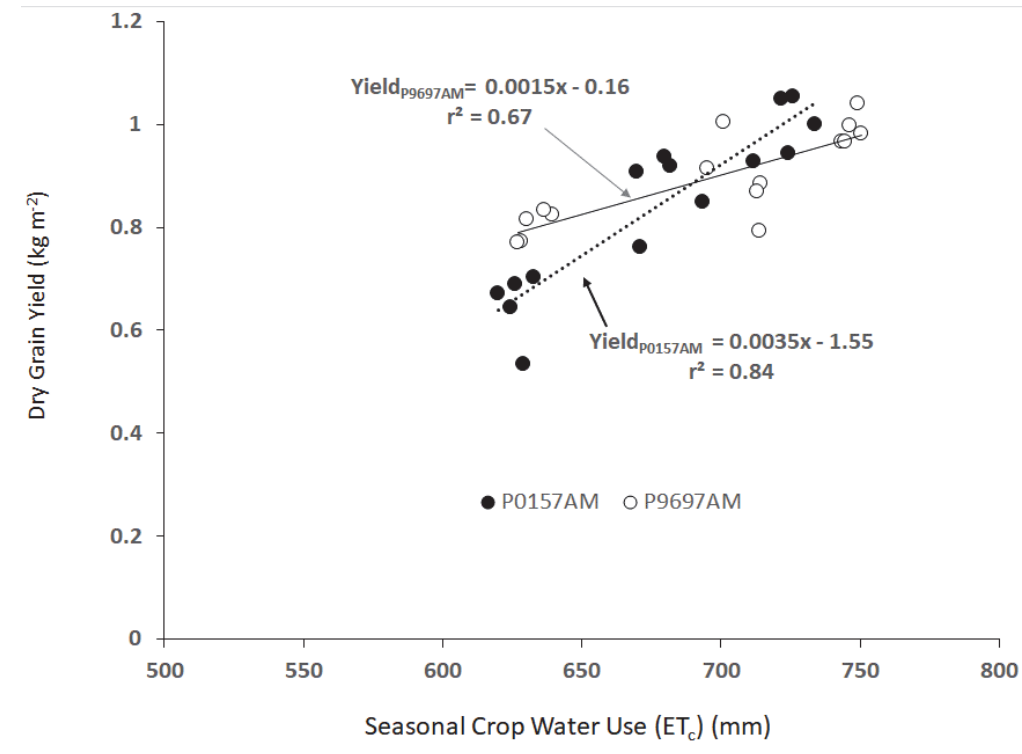

Figure 1. Grain yield (adjusted to wet basis of 15.6\%) plotted against seasonal crop water use for DT corn hybrids P0157AM and P9697AM grown in Bushland, Texas, in 2015. 
Table 3. Mean crop response between drought-tolerant hybrids Pioneer P0157AM and P9697AM grown in 2015 at Bushland, Texas. Mean values followed by the same letter are not significantly different at $\mathbf{p}<0.05$.

\begin{tabular}{|c|c|c|c|c|c|c|c|}
\hline Treatment & $\begin{array}{c}\text { Dry Grain Yield } \\
\left(\mathrm{kg} \mathrm{m}^{-2}\right)\end{array}$ & $\begin{array}{c}\mathrm{ET}_{c} \\
(\mathrm{~mm}) \\
\end{array}$ & $\begin{array}{c}\text { WUE } \\
\left(\mathrm{kg} \mathrm{m}^{-3}\right) \\
\end{array}$ & $\begin{array}{c}\text { Biomass } \\
(\mathrm{g})\end{array}$ & $\begin{array}{l}\text { Kernels } \\
\text { per Ear }\end{array}$ & $\begin{array}{c}\text { Kernel Weight } \\
(\mathrm{mg})\end{array}$ & $\begin{array}{c}\text { Harvest } \\
\text { Index }\end{array}$ \\
\hline \multicolumn{8}{|l|}{ Hybrid } \\
\hline P0157AM & $0.87 \mathrm{a}$ & $783 \mathrm{~b}$ & $1.11 \mathrm{a}$ & $2951 \mathrm{a}$ & $449 \mathrm{a}$ & $240 \mathrm{a}$ & $0.59 \mathrm{a}$ \\
\hline P9697AM & $0.91 \mathrm{a}$ & $797 \mathrm{a}$ & $1.14 \mathrm{a}$ & $2819 \mathrm{a}$ & $445 \mathrm{a}$ & $242 \mathrm{a}$ & $0.52 \mathrm{~b}$ \\
\hline \multicolumn{8}{|l|}{ Hybrid $\times$ Irrigation } \\
\hline $\mathrm{P} 0157 \mathrm{AM} \times I_{100}$ & $0.99 \mathrm{a}$ & $845 \mathrm{a}$ & $1.17 \mathrm{a}$ & $3147 \mathrm{a}$ & $457 \mathrm{a}$ & $267 \mathrm{a}$ & $0.62 \mathrm{a}$ \\
\hline $\mathrm{P} 9697 \mathrm{AM} \times I_{100}$ & $1.01 \mathrm{a}$ & 857 a & $1.18 \mathrm{a}$ & $3032 \mathrm{ab}$ & $453 \mathrm{ab}$ & $265 \mathrm{a}$ & $0.54 \mathrm{~b}$ \\
\hline $\mathrm{P} 0157 \mathrm{AM} \times I_{75}$ & $0.90 \mathrm{~b}$ & $782 \mathrm{c}$ & $1.15 \mathrm{a}$ & $3050 \mathrm{ab}$ & $450 \mathrm{ab}$ & $248 \mathrm{~b}$ & $0.60 \mathrm{ab}$ \\
\hline $\mathrm{P} 9697 \mathrm{AM} \times I_{75}$ & $0.91 \mathrm{~b}$ & $805 \mathrm{~b}$ & $1.13 \mathrm{a}$ & $2815 \mathrm{bc}$ & $447 \mathrm{ab}$ & $239 \mathrm{~b}$ & $0.51 \mathrm{c}$ \\
\hline $\mathrm{P} 0157 \mathrm{AM} \times I_{50}$ & $0.73 \mathrm{~d}$ & $721 \mathrm{~d}$ & $1.01 \mathrm{~b}$ & $2656 \mathrm{c}$ & $429 \mathrm{~b}$ & $205 \mathrm{~d}$ & $0.55 \mathrm{~b}$ \\
\hline $\mathrm{P} 9697 \mathrm{AM} \times I_{50}$ & $0.81 \mathrm{c}$ & $729 \mathrm{~d}$ & $1.11 \mathrm{a}$ & $2612 \mathrm{c}$ & $447 \mathrm{ab}$ & $223 \mathrm{c}$ & $0.52 \mathrm{c}$ \\
\hline
\end{tabular}

precipitation received after the crop had reached physiological maturity. Precipitation totals through harvest (November 2015) were used to calculate seasonal $\mathrm{ET}_{c}$. However, our results for dry grain yield and WUE were similar to the crop responses described by Zhao et al. (2018) for MS DT hybrids P1151AM (yield of $0.92 \mathrm{~kg} \mathrm{~m}^{-2}$ and WUE of $1.28 \mathrm{~kg} \mathrm{~m}^{-3}$ ) and $\mathrm{N} 75 \mathrm{H}$ (yield of $0.83 \mathrm{~kg} \mathrm{~m}^{-2}$ and WUE of $1.13 \mathrm{~kg} \mathrm{~m}^{-3}$ ) grown in 2015 in the THP. The planting date for that study was June 4 (DOY 156).

A comparison of mean yield components between hybrids indicated that biomass, kernels per ear, and kernel weight were similar; however, HI was significantly greater for the P0157AM hybrid. Comparisons between hybrids at the same irrigation level showed that mean biomass, kernels per ear, and kernel weight were similar at the $I_{100}$ and $I_{75}$ treatment levels. However, kernel weight was significantly greater for the P9697AM hybrid in the $I_{50}$ treatment, and HI was significantly greater for the P0157AM hybrid across all three irrigation treatment levels (table 3). Overall, the
P0157AM hybrid required less cumulative irrigation to produce grain yields similar to the P9697AM hybrid and was more efficient in producing economic yield.

\section{COMPARISON OF RESPONSES OF MID-SEASON}

\section{AND EARLY-MATURING DT HYBRIDS}

The MS hybrid (P1151AM) and EM hybrid (P0157AM) were planted in 2016 in the 3-span and 6-span VRI fields, respectively. Uniform irrigations of the MS hybrid were initiated on May 19, 2016, six days after planting, to establish the plant stand. Differential irrigation treatments were started on DOY 160 (June 6) at the V6 stage. Post-plant irrigations were initiated on DOY 169 (June 17) for the EM hybrid, and differential treatments were started on DOY 177 (June 25). Monthly cumulative rainfall for May, June, and July (DOY 122 to 213) was $35 \mathrm{~mm}$ or less, and the greatest evaporative demand occurred in late June through July (DOY 174 to 213). The MS hybrid was in the VT (tasseling) stage on DOY 197, while the EM hybrid was in the vegetative stages during this hot dry period (fig. 2). The EM hybrid

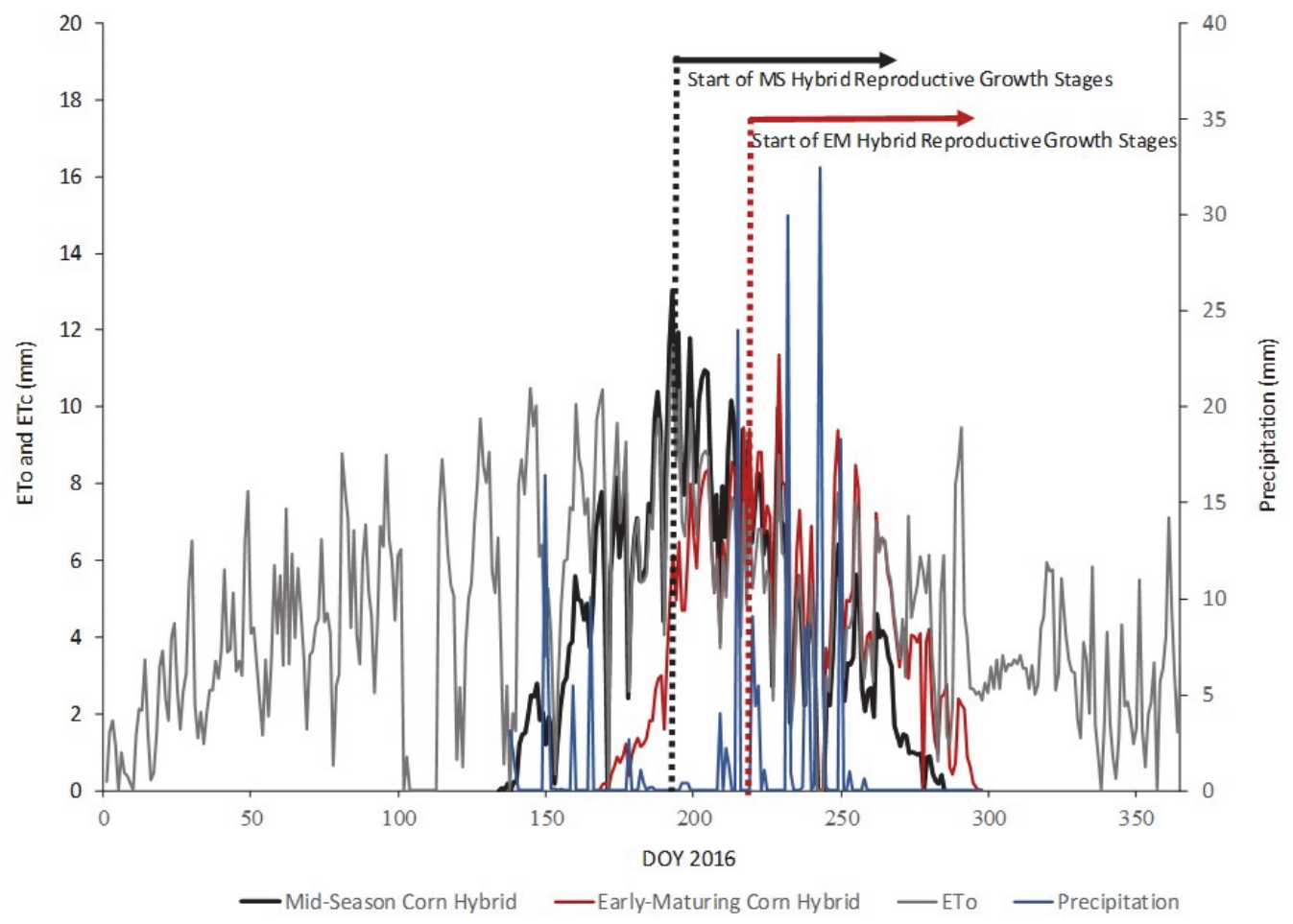

Figure 2. Daily precipitation and calculated reference evapotranspiration $\left(\mathbf{E T}_{o}\right.$; ASCE, 2005) crop water use $\left(\mathbf{E T}_{c}=\mathbf{E T}_{o} \times K_{c}\right.$, where $K_{c}$ values were derived from Bushland, Texas, by Howell et al., 2006) for the mid-season (MS) corn hybrid P1151AM and early-maturing (EM) corn hybrid P0157AM in the 2016 growing season. 
did not reach the VT stage until DOY 224. Sixty-two percent of seasonal rainfall occurred in August. Irrigations for both hybrids were terminated on DOY 231 (August 18), at which time the MS hybrid was in the R5 (dent) stage and the EM hybrid was entering the R3 (milk) stage. The average soil water depletion for the $I_{100}$ EM hybrids was $<6 \%$ in the top $1.5 \mathrm{~m}$ on DOY 253 , when the crop was in the R4 (dough) stage, and $<10 \%$ when the crop was in the R5 (dent) stage on DOY 264, indicating adequate plant-available water in the root zone (data not shown).

The MS DT hybrid was harvested on DOY 286 (October 12), and the EM DT hybrid was harvested on DOY 298 (October 24). Mean cumulative irrigation amounts of 445, $396,254,157$, and $10 \mathrm{~mm}$ were applied to the MS hybrid in the $I_{100}, I_{80}, I_{50}, I_{30}$, and $I_{0}$ irrigation treatments, respectively. For the EM DT hybrid, mean cumulative irrigation amounts were $368,304,229$, and $178 \mathrm{~mm}$ were applied in the $I_{100}, I_{80}$, $I_{50}$, and $I_{30}$ irrigation treatments, respectively. Environmental conditions were more favorable for the EM DT hybrid, i.e., lower evaporative demand and rainfall occurred during the reproductive growth stages.

A statistical analysis of the crop response was performed separately for each hybrid (table 4), showing that irrigation treatment significantly affected the crop response for both hybrids. Deficit irrigation treatments $\left(<I_{80}\right)$ resulted in significant decreases in grain yield and $\mathrm{ET}_{c}$ in the EM DT hybrid. Mean WUE was numerically greatest at the moderate deficit treatment level $\left(I_{50}\right)$ but only significantly greater compared with the $I_{30}$ treatment level. An analysis of yield components demonstrated that deficit irrigation at the moderate $\left(I_{50}\right)$ and severe $\left(I_{30}\right)$ levels significantly reduced biomass and kernels per ear compared with the $I_{100}$ treatment. The $I_{30}$ treatment also negatively impacted HI. We did not establish $I_{0}$ treatment plots for the EM DT hybrid. However, our assumption was that some grain would have been produced because the mean initial soil water readings for all plots across the field on June 29 (13 days after planting) was nearly full $(488 \pm 10 \mathrm{~mm})$, and consistent precipitation occurred in early August when the EM DT hybrid entered the early reproductive stage.

For the MS hybrid, a significant reduction in grain yield and WUE occurred at irrigation treatment levels $<I_{80}$. Seasonal $\mathrm{ET}_{c}$ was significantly different for each irrigation treatment level. The drought conditions and high temperatures suppressed grain production in the $I_{0}$ irrigation treatments. The yield component analysis showed that deficit irrigation treatments $<I_{80}$ significantly reduced biomass. Kernels per ear, kernel weight, and $\mathrm{HI}$ were significantly reduced at the $I_{30}$ treatment level.

Grain yield as a function of $\mathrm{ET}_{c}$ was linear for both hybrids (fig. 3). Mean plant density ( 9 plants $\mathrm{m}^{-2}$ ) was the same for both hybrids (data not shown); however, mean biomass and kernel weight were numerically greater for the MS hy-

Table 4. Mean crop response between drought-tolerant hybrids Pioneer P0157AM (EM) and P1151AM (MS) grown in 2016 at Bushland, Texas. Mean values followed by the same letter are not significantly different at $\mathbf{p}<0.05$.

\begin{tabular}{|c|c|c|c|c|c|c|c|}
\hline $\begin{array}{c}\text { Treatment } \\
(\text { Hybrid } \times \text { Irrigation })\end{array}$ & $\begin{array}{c}\text { Dry Grain Yield } \\
\left(\mathrm{kg} \mathrm{m}^{-2}\right)\end{array}$ & $\begin{array}{c}\mathrm{ET}_{c} \\
(\mathrm{~mm})\end{array}$ & $\begin{array}{c}\text { WUE } \\
\left(\mathrm{kg} \mathrm{m}^{-3}\right)\end{array}$ & $\begin{array}{l}\text { Biomass } \\
(\mathrm{g})\end{array}$ & $\begin{array}{l}\text { Kernels } \\
\text { per Ear }\end{array}$ & $\begin{array}{l}\text { Kernel Weight } \\
(\mathrm{mg})\end{array}$ & $\begin{array}{c}\text { Harvest } \\
\text { Index }\end{array}$ \\
\hline $\mathrm{P} 0157 \mathrm{AM} \times I_{100}$ & $1.08 \mathrm{a}$ & $646 \mathrm{a}$ & $1.67 \mathrm{ab}$ & $3049 \mathrm{a}$ & $484 \mathrm{a}$ & $254 \mathrm{~b}$ & $0.58 \mathrm{a}$ \\
\hline $\mathrm{P} 0157 \mathrm{AM} \times I_{80}$ & $1.04 \mathrm{a}$ & $604 \mathrm{~b}$ & $1.72 \mathrm{ab}$ & $2952 \mathrm{ab}$ & $471 \mathrm{a}$ & $268 \mathrm{a}$ & $0.57 \mathrm{a}$ \\
\hline $\mathrm{P} 0157 \mathrm{AM} \times I_{50}$ & $0.95 \mathrm{~b}$ & $535 \mathrm{c}$ & $1.78 \mathrm{a}$ & $2846 \mathrm{~b}$ & $430 \mathrm{~b}$ & $254 \mathrm{~b}$ & $0.57 \mathrm{a}$ \\
\hline $\mathrm{P} 0157 \mathrm{AM} \times I_{30}$ & $0.81 \mathrm{c}$ & $505 \mathrm{~d}$ & $1.60 \mathrm{~b}$ & $2523 \mathrm{c}$ & $395 \mathrm{c}$ & $256 \mathrm{~b}$ & $0.55 \mathrm{~b}$ \\
\hline $\mathrm{P} 1151 \mathrm{AM} \times I_{100}$ & $1.53 \mathrm{a}$ & $706 \mathrm{a}$ & $2.17 \mathrm{a}$ & $3578 \mathrm{a}$ & $489 \mathrm{a}$ & $316 \mathrm{ab}$ & $0.61 \mathrm{a}$ \\
\hline $\mathrm{P} 1151 \mathrm{AM} \times I_{80}$ & $1.45 \mathrm{a}$ & $670 \mathrm{~b}$ & $2.16 \mathrm{a}$ & $3755 \mathrm{a}$ & $511 \mathrm{a}$ & $323 a$ & $0.59 \mathrm{a}$ \\
\hline $\mathrm{P} 1151 \mathrm{AM} \times I_{50}$ & $1.01 \mathrm{~b}$ & $548 \mathrm{c}$ & $1.84 \mathrm{~b}$ & $2887 \mathrm{~b}$ & $439 a$ & $313 \mathrm{~b}$ & $0.55 \mathrm{a}$ \\
\hline $\mathrm{P} 1151 \mathrm{AM} \times I_{30}$ & $0.22 \mathrm{c}$ & $445 \mathrm{~d}$ & $0.49 \mathrm{c}$ & $1547 \mathrm{c}$ & $162 \mathrm{~b}$ & $283 \mathrm{c}$ & $0.17 \mathrm{~b}$ \\
\hline $\mathrm{P} 1151 \mathrm{AM} \times I_{0}$ & $0.00 \mathrm{~d}$ & $251 \mathrm{e}$ & $0.00 \mathrm{~d}$ & $393 \mathrm{~d}$ & $0 \mathrm{~d}$ & $0 \mathrm{~d}$ & N/A \\
\hline
\end{tabular}

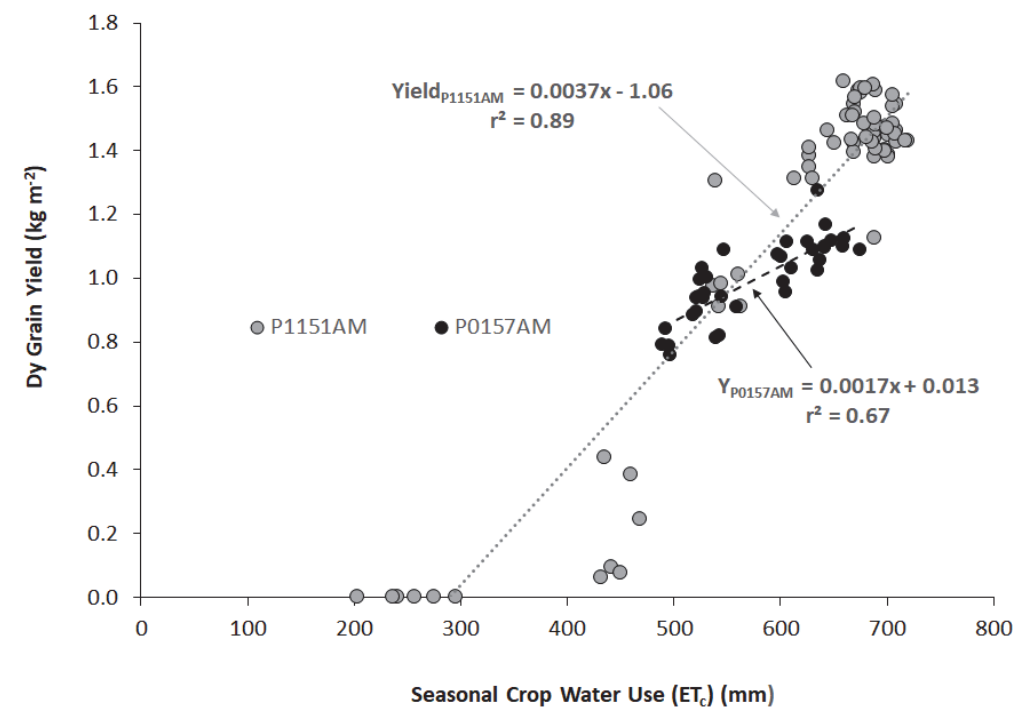

Figure 3. Relationship between grain yield and seasonal crop water use for the early-maturing hybrid P0157AM and the mid-season hybrid P1151AM grown in 2016 at Bushland, Texas. 
brid, while mean kernels per ear and HI were similar between hybrids at the $I_{100}$ and $I_{80}$ irrigation levels (table 4). Although environmental conditions were more favorable for the EM DT hybrid during the crop's reproductive stages, the EM DT grain yields were at least 29\% less compared with the MS hybrid yields at the $I_{100}$ and $I_{80}$ treatment levels. Bonelli et al. (2016) found that grain weight and grain number for Pioneer hybrid P39B77 (CRM of 92 days) were proportionally lower as the sowing date was delayed, indicating that the EM hybrid was prone to limitations in assimilate availability during the grain filling stages.

This study demonstrated potential advantages and disadvantages of planting an EM hybrid relatively late in the growing season. At the $I_{30}$ treatment level, grain yield for the EM DT hybrid was $400 \%$ greater $\left(0.82 \mathrm{~kg} \mathrm{~m}^{-2}\right)$ than grain yield for the MS hybrid, which produced low values of dry grain yield $\left(0.2 \mathrm{~kg} \mathrm{~m}^{-2}\right)$ at the same treatment level. In contrast, at the $I_{100}$ treatment level, grain yield for the MS DT hybrid $\left(1.53 \mathrm{~kg} \mathrm{~m}^{-2}\right)$ was $41 \%$ greater than grain yield for the EM DT hybrid. However, approximately $75 \mathrm{~mm}$ of water was saved in managing the EM hybrid at 100\% replenishment of soil water depletion to field capacity, as compared with the MS DT hybrid. Planting later in the growing season can help producers with adaptation strategies for climate change or with fields that have limited well capacity by shifting peak seasonal evaporative demand away from the reproductive growth stages. Planting EM DT hybrids late in the growing season may also be a strategy to sustain a profit if a producer is confronted with replanting. Producers must consider the potential yield of the existing stand compared with the yield potential of the late-planted EM hybrid. The downside of EM hybrids, as shown in this study, is that they produce less grain yield compared with MS or full-season hybrids, even at irrigation treatment levels that match full $\mathrm{ET}_{c}$ requirements; this is a typical characteristic of EM hybrids (Angel et al., 2017). Howell et al. (1998) also found grain yields to be $15 \%$ less for a fully irrigated EM hybrid (Pioneer 3737) planted on the same day as compared to a fully irrigated full-season hybrid (Pioneer 3245) at the CPRL.

\section{CROP RESPONSE OF MID-SEASON HYBRID \\ P1151AM OVER TWO YEARS}

Corn hybrid P1151AM was again planted in 2017 under the 3-span VRI system on May 17 (DOY 137) following a mild spring, i.e., relatively low maximum air temperatures and $178 \mathrm{~mm}$ of precipitation from January through May. After planting, minimal rainfall occurred for the next 22 days; therefore, four $25 \mathrm{~mm}$ irrigations were applied uniformly across all plots approximately every fifth day. Maximum and minimum daily air temperatures reached their highest values in this part of the growing season. A hailstorm hit on July 2 and damaged leaves and corn stalks throughout the field. The corn was in the seventh leaf stage. The damage from the storm slowed crop maturity by approximately two weeks and resulted in a yield penalty of approximately $19 \%$ as compared with 2016. Klocke et al. (2014) reported similar yield penalties in corn damaged by hail during wet years. Irrigations resumed seven days after the hailstorm and terminated on August 7, when consistent precipitation events resumed. Mean cumulative irrigation amounts were 283, 228, 190, 97, and $43 \mathrm{~mm}$ for the $I_{100}, I_{80}, I_{50}, I_{30}$, and $I_{0}$ levels, respectively. Total rainfall received from May through October was $80 \%$ of seasonal crop water use.

For 2017, grain yield plotted as a function of cumulative seasonal $\mathrm{ET}_{c}$ was curvilinear, and yield amounts in the $I_{100}$ and $I_{80}$ treatments were reduced by at least $28 \%$ compared with grain yields in 2016 (fig. 4). Maximum potential yields for the 2017 growing season were limited by hail damage, biomass was reduced by $10 \%$ to $15 \%$ in the highest irrigation treatments compared with biomass production in 2016 for this hybrid, and WUE was decreased due to large amounts of precipitation received after mid-August. The reduction in grain yield was likely due to the leaf area loss and pitted stalks from the hail damage. Similar results from hail damage were reported by Vasilas et al. (1990) and Mounce et al. (2016). Hail damage in the vegetative stage and heavy precipitation at the reproductive stage also nullified the irrigation treatment effects on grain yield and WUE at the higher irrigation levels $\left(I_{100}, I_{80}\right.$, and $\left.I_{50}\right)$. At deficit levels $\left(I_{30}\right.$ and

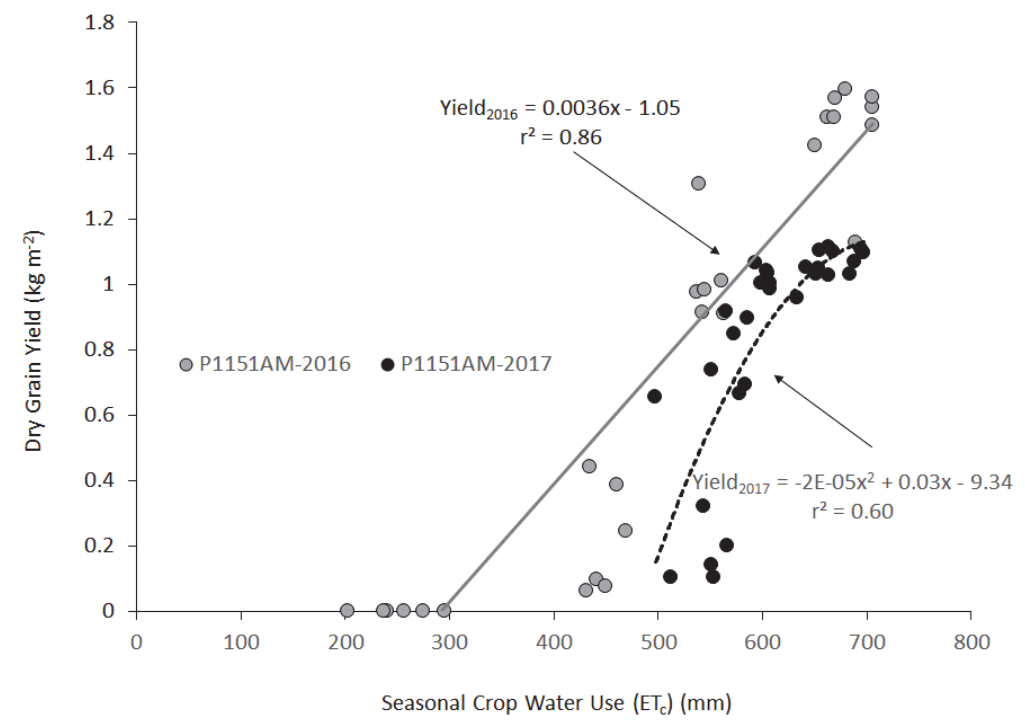

Figure 4. Grain yield of DT hybrid P1151AM plotted against seasonal crop water use $\left(\mathrm{ET}_{c}\right)$ for the 2016 and 2017 growing seasons at Bushland, Texas, in 2016 and 2017. 
Table 5. Mean crop response for drought-tolerant hybrid P1151AM grown in 2017 at Bushland, Texas. Mean values followed by the same letter are not significantly different at $\mathbf{p}<0.05$.

\begin{tabular}{|c|c|c|c|c|c|c|c|}
\hline $\begin{array}{c}\text { Treatment } \\
(\text { Hybrid } \times \text { Irrigation })\end{array}$ & $\begin{array}{c}\text { Grain Yield } \\
\left(\mathrm{kg} \mathrm{m}^{-2}\right)\end{array}$ & $\begin{array}{c}\mathrm{ET}_{c} \\
(\mathrm{~mm})\end{array}$ & $\begin{array}{c}\text { WUE } \\
\left(\mathrm{kg} \mathrm{m}^{-3}\right)\end{array}$ & $\begin{array}{c}\text { Biomass } \\
(\mathrm{g})\end{array}$ & $\begin{array}{l}\text { Kernels } \\
\text { per Ear }\end{array}$ & $\begin{array}{c}\text { Kernel Weight } \\
(\mathrm{mg})\end{array}$ & $\begin{array}{c}\text { Harvest } \\
\text { Index }\end{array}$ \\
\hline $\mathrm{P} 1151 \mathrm{AM} \times I_{100}$ & $1.08 \mathrm{a}$ & $675 a$ & $1.60 \mathrm{a}$ & $3232 \mathrm{a}$ & $416 \mathrm{a}$ & $274 \mathrm{~d}$ & $0.60 \mathrm{a}$ \\
\hline $\mathrm{P} 1151 \mathrm{AM} \times I_{80}$ & $1.05 \mathrm{a}$ & $658 \mathrm{~b}$ & $1.60 \mathrm{a}$ & $3204 \mathrm{a}$ & $396 \mathrm{a}$ & $280 \mathrm{~cd}$ & $0.58 \mathrm{a}$ \\
\hline $\mathrm{P} 1151 \mathrm{AM} \times I_{50}$ & $0.99 \mathrm{a}$ & $593 \mathrm{c}$ & $1.67 \mathrm{a}$ & $3068 \mathrm{a}$ & $353 \mathrm{~b}$ & $297 \mathrm{~b}$ & $0.57 \mathrm{a}$ \\
\hline $\mathrm{P} 1151 \mathrm{AM} \times I_{30}$ & $0.65 \mathrm{~b}$ & $555 \mathrm{~d}$ & $1.17 \mathrm{~b}$ & $2594 \mathrm{~b}$ & $259 \mathrm{c}$ & $309 \mathrm{a}$ & $0.48 \mathrm{~b}$ \\
\hline $\mathrm{P} 1151 \mathrm{AM} \times I_{0}$ & $0.14 \mathrm{c}$ & $546 \mathrm{~d}$ & $0.26 \mathrm{c}$ & $1055 \mathrm{c}$ & $72 \mathrm{~d}$ & $293 \mathrm{bc}$ & $0.16 \mathrm{c}$ \\
\hline
\end{tabular}

$I_{0}$ ), grain yield, WUE, biomass, kernels per ear, and HI were significantly reduced (table 5). The quality of the cobs and kernels in the lower irrigation treatments $\left(I_{50}\right.$ and $\left.I_{30}\right)$ also had a greater susceptibility to fungal disease. The combination of water stress and disease may have further reduced grain yields (Fullerton et al., 1974; Kostandi and Soliman, 1998; Robertson et al., 2011). Mean dry grain yield at the $I_{100}$ treatment level for the P1151AM hybrid grown in this study in 2016 was numerically greater than for mid-season DT hybrid P0876HR $\left(1.45 \mathrm{~kg} \mathrm{~m}^{-2}\right)$ managed at the $I_{100}$ treatment level at the CPRL in 2014 (a highly favorable year), but WUE was slightly less for the P1151AM hybrid. Dry grain yields for the P1151AM hybrid managed at the $I_{80}$ treatment level in 2017 were similar to dry grain yields for the DT hybrid P0876HR managed at the $I_{75}$ irrigation treatment level in the more droughty year of 2013 (Mounce et al., 2016), but mean WUE was again less for the P1151AM hybrid. Days to relative maturity for hybrid P0876HR was 108 , and planting dates in 2013 and 2014 were also in mid-May.

Grain yields and WUE in the $I_{30}$ and $I_{0}$ treatments were greater in 2017 (table 5) as compared to 2016 (table 4), despite the negative impacts from hail and disease. These results were similar to those reported by Klocke et al. (2014), where grain yields for corn damaged by hail prior to tasseling, and under deficit irrigation treatment, were greater than yields produced in dry years with no hail. The timing of precipitation and cooler air temperatures during the reproductive stages of crop development in 2017 likely aided in kernel production and grain filling in these more deficit irrigation treatments.

\section{DT HYBRID RESPONSE COMPARED WITH HistoRicAl CORN RESPONSE IN THP}

Although grain yields can be influenced by climate, soil type (Tolk and Evett, 2012), planting date (Tsimba et al., 2013), experimental approach, irrigation application method (Schneider and Howell, 1998), irrigation management (Howell et al., 1989), and hybrid, plotting the relationship between historical corn grain yields and seasonal $\mathrm{ET}_{c}$ for corn grown in the THP region gives an idea of the potential upper and lower limits for corn water productivity in the THP. This information is important to producers because it provides a range for potential grain yields as well as total water requirements for corn production under sprinkler irrigation in the THP region (fig. 5). Since the late 1980s, sprinkler irrigation systems have been used at the CPRL in Bushland, Texas, for irrigation studies. The corn hybrid studies in the THP region performed by Hao et al. (2015a, 2015b) and Zhao et al. (2018) were also managed under sprinkler irrigation systems. Mean dry grain yield for $\mathrm{CONV}$ corn grown at Bushland and Etter and irrigated at $50 \%$ of ET or greater was calculated to be $1.09 \mathrm{~kg} \mathrm{~m}^{-2}$, and mean $\mathrm{ET}_{c}$ was $683 \mathrm{~mm}$. For DT corn hybrids grown in the THP region from 2011 to 2015 (not including data from the current study), mean dry grain yields were $1.13 \mathrm{~kg} \mathrm{~m}^{-2}$, and mean $\mathrm{ET}_{c}$ was $598 \mathrm{~mm}$. Mean dry grain yield for all DT hybrids grown in this study (20152017) and irrigated at treatment levels $>I_{30}$ was $1.02 \mathrm{~kg} \mathrm{~m}^{-2}$, and mean $\mathrm{ET}_{c}$ was $616 \mathrm{~mm}$. Maximum historical grain yields and WUE occurred in 2014 for both CONV (Pioneer 33Y75, $1.7 \mathrm{~kg} \mathrm{~m}^{-2}$ and $2.97 \mathrm{~kg} \mathrm{~m}^{-3}$, respectively) and DT (Pioneer, P0876HR, $1.6 \mathrm{~kg} \mathrm{~m}^{-2}$ and $2.98 \mathrm{~kg} \mathrm{~m}^{-3}$, respectively) corn hybrids. Precipitation during the 2014 growing season was greater than the average seasonal rainfall for the CPRL, and maximum daily air temperatures were moderate. For this study, the maximum mean grain yield $\left(1.53 \mathrm{~kg} \mathrm{~m}^{-2}\right)$ and WUE $\left(2.17 \mathrm{~kg} \mathrm{~m}^{-3}\right)$ occurred in 2016 in the MS DT hybrid (P1151AM). Minimum historical WUE in the CONV hybrids occurred in 1987 and 2013. The 2013 growing season was relatively droughty; however, there is no clear reason why WUE was minimal in 1987. For historical DT hybrids, the minimum WUE $\left(1.08 \mathrm{~kg} \mathrm{~m}^{-3}\right)$ occurred during the exceptional drought year of 2011 (Hao et al., 2015b). In this study, the minimum WUE occurred in the $I_{30}$ treatment for the MS DT hybrid in 2016. The minimum historical WUE for higher levels of irrigation occurred in CONV corn in 1992 and 1993. Seasonal precipitation in 1992 and 1993 was higher than normal (Howell et al., 1995), and precipitation in 1992 interfered with fertilizer applications. Rainfed plots in 1994 and 1995 yielded no grain, similar to the results in this study for the MS hybrid planted in 2016. Schneider and Howell (1998) reported limited rainfall in July 1994 and less than average rainfall throughout the 1995 growing season. The inadequate rainfall was likely the main factor limiting yields to values near the trendline shown in figure 5 . With the exception of the EM DT corn hybrids planted in 2015, the WUE of moderately $\left(I_{50}\right)$ and well irrigated $\left(>I_{50}\right)$ DT corn hybrids in this study and of historical DT hybrids grown in the THP were near or above the trendline for corn grain yields plotted against total seasonal $\mathrm{ET}_{c}$ (fig. 5).

The $\mathrm{ET}_{c}$ threshold for grain production (for all years shown) was in the ranges of 375 to $500 \mathrm{~mm}$ for CONV corn hybrids and 425 to $575 \mathrm{~mm}$ for DT hybrids grown in 2016 and 2017. The recent thresholds for the DT hybrids are greater than those discussed by Howell et al. (1998) for sprinkler irrigation using low-energy precision application (LEPA) and for drip-irrigated corn grown at Bushland. Similar to yield values, $\mathrm{ET}_{c}$ thresholds vary with hybrid, irrigation method, soil type (Tolk et al., 1998), and climate (Klocke et al., 2014). This indicates that DT hybrids do not have a yield advantage over CONV corn hybrids at severe deficit irrigation levels nor in rainfed treatments in times of drought. The comparison of grain yields as a function of $\mathrm{ET}_{c}$ 


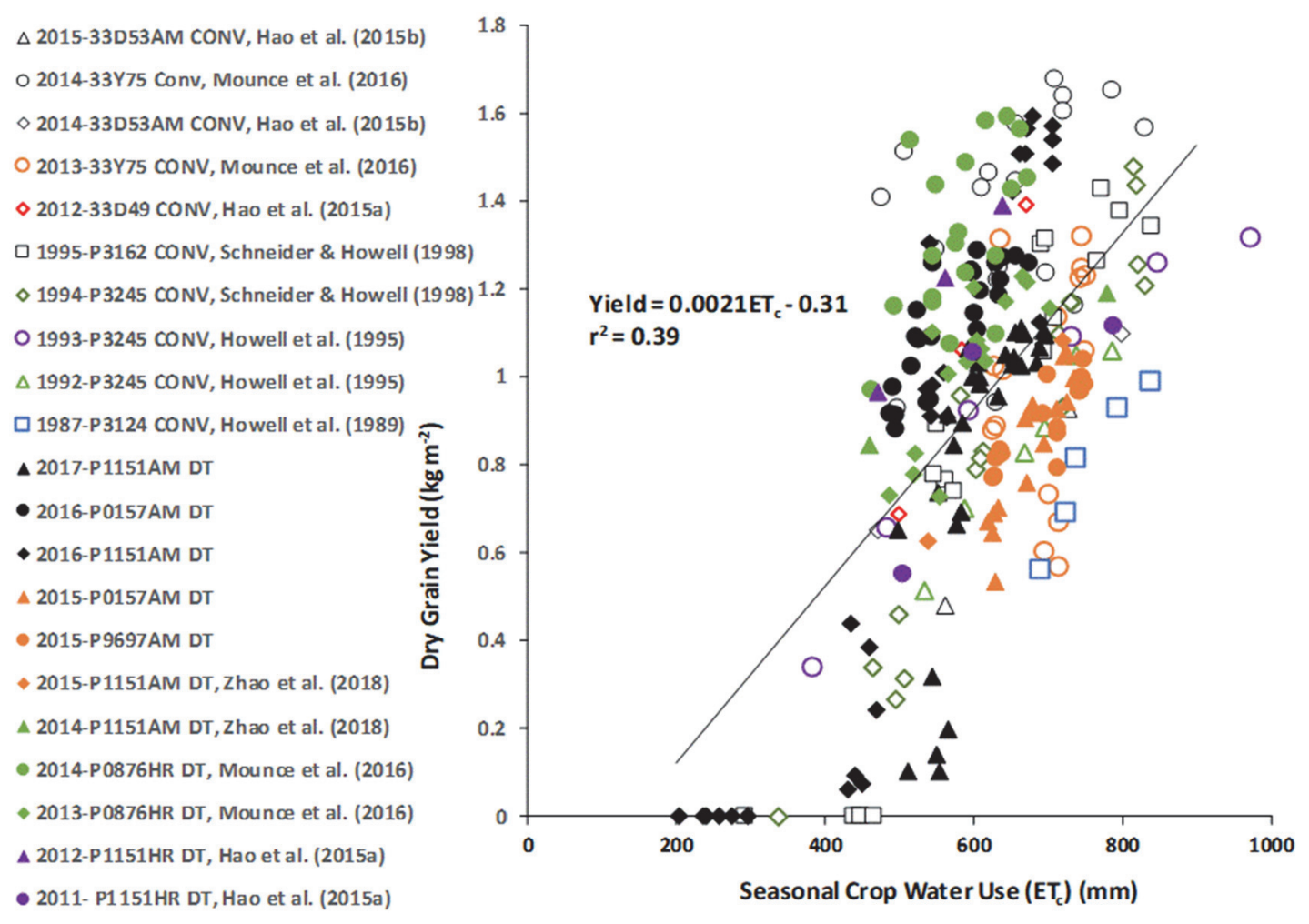

Figure 5. Dry grain yield plotted against seasonal crop water use for corn grown in Bushland, Texas, under sprinkler irrigation systems. Conventional hybrids (CONV) are represented by open symbols, and drought-tolerant hybrids (DT) are represented by solid symbols.

for DT and CONV corn hybrids grown in the THP does not indicate that DT yields outperformed CONV yields under drought conditions. However, figure 5 indicates that DT hybrids were able to consistently produce grain yields that were comparable to or better than yields produced by CONV hybrids grown in the same region. The commensurate performance of DT hybrids in low-stress seasons in the THP region is in agreement with the findings of other studies for DT corn grown in different regions of the U.S. (Adee et al., 2016; Gaffney et al., 2015) and in the THP (Hao et al., 2015a, 2015b, 2016; Zhao et al., 2018).

\section{CONCLUSION}

The data from this three-year study demonstrated that crop responses of drought-tolerant (DT) corn hybrids are influenced by climate variability, planting date, and hybrid type. Grain yields among the different DT hybrids irrigated at levels close to ET demand were similar to historical yields for CONV hybrids grown in the Texas High Plains (THP) in recent years, and greater than CONV hybrids grown in earlier years (1987 and the 1990s). DT hybrids did not demonstrate yield penalties during favorable growing seasons and may be beneficial in reducing cumulative irrigation requirements for corn in the THP region. However, during drought seasons, DT hybrid response was not improved over CONV hybrids under severe deficit irrigation. At smaller irrigation amounts, yields can be greater for EM corn hybrids compared with mid-season and CONV hybrids. However, maximum yields for EM DT hybrids were less than for MS DT and CONV corn hybrids grown at the CPRL in Bushland,
Texas. This study demonstrated that MS DT corn hybrid P1151AM, irrigated at a level to fully meet evapotranspiration demand, resulted in grain yield and WUE levels that were near the upper limit for corn produced in the THP region. Further research is needed to determine the constancy of response among different DT hybrids under favorable and drought conditions.

\section{ACKNOWLEDGEMENTS}

The research reported in this article is funded by the Ogallala Aquifer Program (OAP), a consortium between the USDA Agricultural Research Service, Kansas State University, Texas AgriLife Extension Service and Research, Texas Tech University, and West Texas A\&M University. This article is also part of the OAP Center-Pivot Technology Transfer effort. This material is based in part on work supported by the USDA National Institute of Food and Agriculture under Award No. 2016-67021-24420.

\section{REFERENCES}

Adee, E., Roozeboom, K., Balboa, G. R., Schlegel, A., \& Ciampitti, I. A. (2016). Drought-tolerant corn hybrids yield more in drought-stressed environments with no penalty in non-stressed environments. Frontiers Plant Sci., 7(1534). https://doi.org/10.3389/fpls.2016.01534

Amosson, S., Nair, S., Guerrero, B., Marek, T., \& Jones, D. (2014). Corn production in the Texas High Plains: Gains in productivity and water use efficiency. Prepared for Texas Corn Producers.

Angel, J. R., Widhalm, M., Todey, D., Massey, R., \& Biehl, L. (2017). The U2U corn growing degree day tool: Tracking corn growth across the U.S. Corn Belt. Climate Risk Mgmt., 15, 7381. https://doi.org/10.1016/j.crm.2016.10.002 
ASCE. (2005). The ASCE standardized reference

evapotranspiration equation. Report by the ASCE Task

Committee on Standardization of Reference Evapotranspiration. Reston, VA: ASCE.

Bonelli, L. E., Monzon, J. P., Cerrudo, A., Rizzalli, R. H., \& Andrade, F. H. (2016). Maize grain yield components and source-sink relationship as affected by the delay in sowing date. Field Crops Res., 198, 215-225. https://doi.org/10.1016/j.fcr.2016.09.003

Chang, J., Clay, D. E., Hansen, S. A., Clay, S. A., \& Schumacher, T. E. (2013). Water stress impacts on transgenic drought-tolerant corn in the northern Great Plains. Agron. J., 106(1), 125-130. https://doi.org/10.2134/agronj2013.0076

Colaizzi, P. D., Schneider, A. D., Evett, S. R., \& Howell, T. A. (2004). Comparison of SDI, LEPA, and spray irrigation performance for grain sorghum. Trans. ASAE, 47(5), 1477-1492. https://doi.org/10.13031/2013.17628

Cooper, M., Gho, C., Leafgren, R., Tang, T., \& Messina, C. (2014). Breeding drought-tolerant maize hybrids for the U.S. Corn Belt: Discovery to product. J. Exp. Botany, 65(21), 6191-6204. https://doi.org/10.1093/jxb/eru064

Evett, S. R. (2008). Chapter 3: Neutron moisture meters. In S. R. Evett, L. K. Heng, P. Moutonnet, \& M. L. Nguyen (Eds.), Field estimation of soil water content: A practical guide to methods, instrumentation, and sensor technology (pp. 39-54). Vienna, Austria: International Atomic Energy. Retrieved from https://www-pub.iaea.org/MTCD/Publications/PDF/TCS30 web.pdf

Fullerton, R. A., Scott, D. J., \& Graham, G. J. (1974). Effect of fungicides on the control of head smut of maize, and the relationship between infection level and crop yield. New Zealand J. Exp. Agric., 2(2), 177-179. https://doi.org/10.1080/03015521.1974.10425757

Gaffney, J., Schussler, J., Loffler, C., Cai, W., Paszkiewicz, S., Messina, C., ... Cooper, M. (2015). Industry-scale evaluation of maize hybrids selected for increased yield in drought-stress conditions of the U.S. Corn Belt. Crop Sci., 55(4), 1608-1618. https://doi.org/10.2135/cropsci2014.09.0654

Gilmore, E. C., \& Rogers, J. S. (1958). Heat units as a method of measuring maturity in corn. Agron. J., 50(10), 611-615. https://doi.org/10.2134/agronj1958.00021962005000100014x

Hao, B., Xue, Q., Marek, T. H., Jessup, K. E., Becker, J., Hou, X., ... Howell, T. A. (2015b). Water use and grain yield in droughttolerant corn in the Texas High Plains. Agron. J., 107(5), 19221930. https://doi.org/10.2134/agronj15.0133

Hao, B., Xue, Q., Marek, T. H., Jessup, K. E., Hou, X., Xu, W., ... Bean, B. W. (2015a). Soil water extraction, water use, and grain yield by drought-tolerant maize on the Texas High Plains. Agric. Water Mgmt., 155, 11-21. https://doi.org/10.1016/j.agwat.2015.03.007

Hao, B., Xue, Q., Marek, T. H., Jessup, K. E., Hou, X., Xu, W., ... Bean, B. W. (2016). Radiation-use efficiency, biomass production, and grain yield in two maize hybrids differing in drought tolerance. J. Agron. Crop Sci., 202(4), 269-280. https://doi.org/10.1111/jac.12154.

Howell, T. A. (2001). Enhancing water use efficiency in irrigated agriculture. Agron. J., 93(2), 281-289. https://doi.org/10.2134/agronj2001.932281x

Howell, T. A., Copeland, K. S., Schneider, A. D., \& Dusek, D. A. (1989). Sprinkler irrigation management for corn: Southern Great Plains. Trans. ASAE, 32(1), 147-154. https://doi.org/10.13031/2013.30974

Howell, T. A., Evett, S. R., Tolk, J. A., Copeland, K. S., Dusek, D. A., \& Colaizzi, P. D. (2006). Crop coefficients developed at Bushland, Texas, for corn, wheat, sorghum, soybean, cotton, and alfalfa. In R. Graham (Ed.), Proc. ASCE-EWRI World Environ.
Water Res. Congress. Reston, VA: ASCE. https://doi.org/10.1061/40856(200)260

Howell, T. A., Tolk, J. A., Schneider, A. D., \& Evett, S. R. (1998). Evapotranspiration, yield, and water use efficiency of corn hybrids differing in maturity. Agron. J., 90(1), 3-9. https://doi.org/10.2134/agronj1998.00021962009000010002x

Howell, T. A., Yazar, A., Schneider, A. D., Dusek, D. A., \& Copeland, K. S. (1995). Yield and water use efficiency of corn in response to LEPA irrigation. Trans. ASAE, 38(6), 1737-1747. https://doi.org/10.13031/2013.28001

Klocke, N. L., Currie, R. S., Kisekka, I., \& Loyd, R. S. (2014). Corn and grain sorghum response tolimited irrigation, drought, and hail. Appl. Eng. Agric., 30(6), 915-924. https://doi.org/10.13031/aea.30.10810

Klocke, N. L., Currie, R. S., Tomsicek, D. J., \& Koehn, J. (2011). Corn yield response to deficit irrigation. Trans. ASABE, 54(3), 931-940. https://doi.org/10.13031/2013.37118

Klocke, N. L., Payero, J. O., \& Schneekloth, J. P. (2007). Longterm response of corn to limited irrigation and crop rotations. Trans. ASABE, 50(6), 2117-2124. https://doi.org/10.13031/2013.24113

Kostandi, S. F., \& Soliman, M. F. (1998). Water stress and N fertilization effects on yield and smut disease incidence in corn (Zea mays L.). J. Agron. Crop Sci., 180(3), 151-157. https://doi.org/10.1111/j.1439-037X.1998.tb00385.x

Lindsey, A. J., \& Thomison, P. R. (2016). Drought-tolerant corn hybrid and relative maturity yield response to plant population and planting date. Agron. J., 108(1), 229-242. https://doi.org/10.2134/agronj2015.0200

Littell, R. C. (2006). SAS for mixed models (2nd ed). Cary, NC: SAS Institute, Inc.

Lyle, W. M., \& Bordovsky, J. P. (1995). LEPA corn irrigation with limited water supplies. Trans. ASAE, 38(2), 455-462. https://doi.org/10.13031/2013.27853

Lyle, W. M., \& Dixon, D. R. (1977). Basin tillage for rainfall retention. Trans. ASAE, 20(6), 1013-1017. https://doi.org/10.13031/2013.35693

Mannion, A. M., \& Morse, S. (2012). Biotechnology in agriculture: Agronomic and environmental considerations and reflections based on 15 years of GM crops. Prog. Phys. Geogr., 36(6), 747763. https://doi.org/10.1177/0309133312457109

McMaster, G. S., \& Wilhelm, W. W. (1997). Growing degree-days: One equation, two interpretations. Agric. Forest Meteorol., 87(4), 291-300. https://doi.org/10.1016/S0168-1923(97)00027-0

Mounce, R. B., O'Shaughnessy, S. A., Blaser, B. C., Colaizzi, P. D., $\&$ Evett, S. R. (2016). Crop response of drought-tolerant and conventional maize hybrids in a semiarid environment. Irrig. Sci., 34(3), 231-244. https://doi.org/10.1007/s00271-016-0497-5

Nuccio, M. L., Paul, M., Bate, N. J., Cohn, J., \& Cutler, S. R. (2018). Where are the drought-tolerant crops? An assessment of more than two decades of plant biotechnology effort in crop improvement. Plant Sci., 273, 110-119. https://doi.org/10.1016/j.plantsci.2018.01.020

O’Shaughnessy, S. A., Urrego, Y. F., Evett, S. R., Colaizzi, P. D., \& Howell, T. A. (2013). Assessing application uniformity of a variable-rate irrigation system in a windy location. Appl. Eng. Agric., 29(4), 497-510. https://doi.org/http://doi.org/10.13031/aea.29.9931

Robertson, A. E., Munkvold, G. P., Hurburgh, C. R., \& Ensley, S. (2011). Effects of natural hail damage on ear rots, mycotoxins, and grain quality characteristics of corn. Agron. J., 103(1), 193199. https://doi.org/10.2134/agronj2010.0276

Schneider, A. D., \& Howell, T. A. (1998). LEPA and spray irrigation of corn: Southern High Plains. Trans. ASAE, 41(5), 1391-1396. https://doi.org/10.13031/2013.17313

Tolk, J. A., \& Evett, S. R. (2012). Lower limits of crop water use in 
three soil textural classes. SSSA J., 76(2), 607-616. https://doi.org/10.2136/sssaj2011.0248

Tolk, J. A., Howell, T. A., \& Evett, S. R. (1998). Evapotranspiration and yield of corn grown on three High Plains soils. Agron. J., 90(4), 447-454. 10.2134/agronj1998.00021962009000040001x

Tsimba, R., Edmeades, G. O., Millner, J. P., \& Kemp, P. D. (2013). The effect of planting date on maize: Phenology, thermal time durations, and growth rates in a cool-temperate climate. Field Crops Res., 150, 145-155. https://doi.org/10.1016/j.fcr.2013.05.021

USDA-NASS. (2014). Census of Agriculture, Special Studies: 2013 Farm and Ranch Irrigation Survey. Washington, DC: USDANASS. Retrieved from https://www.agcensus.usda.gov/Publications/2012/Online_Reso urces/Farm_and_Ranch_Irrigation_Survey/

USDA-NRCS. (2010). Soil Survey TX 375 : Potter County, Texas. Washington, DC: USDA Natural Resources Conservation Service.

Retrieved from
https://websoilsurvey.sc.egov.usda.gov/App/WebSoilSurvey.asp

Vasilas, B. L., Fuhrmann, J. J., \& Taylor, R. W. (1990). Response of three corn hybrids to defoliation of neighboring plants. Canadian J. Plant. Sci., 71(2), 311-315. https://doi.org/10.4141/cjps91-045

Wagner, K. (2012). Status and trends of irrigated agriculture in Texas. College Station, TX: Texas Water Resources Institute. Retrieved from http://twri.tamu.edu/docs/education/2012/em115.pdf

Weinheimer, J., Johnson, P., Mitchell, D., Johnson, J., \& Kellison, R. (2013). Texas High Plains initiative for strategic and innovative irrigation management and conservation. J. Contemp. Water Res. Educ., 151(1), 43-49. https://doi.org/10.1111/j.1936704X.2013.03150.x

Zhao, J., Xue, Q., Jessup, K. E., Hao, B., Hou, X., Marek, T. H., ... Brauer, D. K. (2018). Yield and water use of drought-tolerant maize hybrids in a semiarid environment. Field Crops Res., 216, 1-9. https://doi.org/10.1016/j.fcr.2017.11.001 